\title{
Manajer Risiko: Peran Kepala MTs N 1 Kota Yogyakarta Dalam Pembelajaran Daring Masa Pandemi Covid-19
}

\author{
Irwanto \\ UIN Sunan Kalijaga Yogyakarta \\ irwanto@uin-suka.ac.id \\ Zainal Arifin \\ UIN Sunan Kalijaga Yogyakarta \\ zainal.arifin@uin-suka.ac.id
}

\begin{abstract}
The transition of the learning system from offline to online raises new problems at the teacher, the learning process is not optimal, and the process of understanding teachers who do not understand IT. The principal as the school manager must be wise and decisive in analysing issues of education management strategies in school management practices. This study aims to analyse the role of madrasa principal in online learning during the Covid-19 pandemic risk management perspective in MTs $N 1$ Yogyakarta City. This research uses a qualitative approach. Data collected through in-depth interviews and observation. The results showed that the principal of MTs $N 1$ Yogyakarta City as the Risk. Manager had carried out three stages of risk management, first (1) risk assessment to identify online learning problems during the Covid-19 pandemic, (2) risk mitigation, to ease the burden on teachers and students in the learning process through the policy of providing internet quota subsidies for teachers and students who are unable and do not assign too many assignments to students, and (3) risk evaluation, to see the problems of the online learning process through reports or complaints from both teachers and students. The role of the madrasa head as a Risk. Manager must be to minimize, even eliminate the risk or adverse effects of the learning process during the Covid-19 pandemic. Online learning policies, giving quota subsidies, and reducing school work as a form of action to reduce the risk of being stricken with Covid-19 and alleviate psychological burdens, especially for students.
\end{abstract}

Keywords: Principal, risk manager, covid-19, online learning

Abstrak: Peralihan sistem pembelajaran dari luring ke daring menimbulkan persoalan baru bagi guru, proses pembelajaran yang tidak optimal, dan proses pemahaman guru yang kurang memahami IT. Kepala sekolah selaku manajer sekolah harus bijak dan tegas dalam menganalisa persoalan starategi manejemen Pendidikan dalam praktek pengelolaan sekolah. Penelitian ini bertujuan untuk manganalisis peran kepala madrasah dalam pembelajaran daring masa pandemi Covid-19 perspektif manajemen risiko di MTs N 1 Kota Yogyakarta. Penelitian ini menggunakan pendekatan kualitatif. Data dikumpulkan melalui wawancara mendalam dan observasi. Hasil penelitian menunjukan bahwa kepala MTs N 1 Kota Yogyakarta sebagai manajerrisiko telah melakukan tiga tahap manajemen risiko, pertama, (1) penilaian risiko untuk mengindetifikasi masalah pembelajaran daring pada masa pandemi Covid-19, (2) peringanan risiko, untuk meringankan beban bagi guru dan peserta didik dalam proses pembelajaran melalui kebijakan pemberian subsidi kuota internet bagi guru dan peserta didik yang tidak mampu dan tidak memberikan tugas terlalu banyak kepada peserta didik, dan (3) evaluasi risiko, untuk melihat problem proses pembelajaran daring melalui laporan atau keluhan baik dari guru maupun peserta didik. Peran kepala madrasah sebagai manajer risiko harus bisa 
190 | Tadbir : Jurnal Studi Manajemen Pendidikan, Vol. 4, No. 2, 2020

meminimalisir, bahkan menghilangkan risiko atau dampak buruk proses pembelajaran pada masa pandemi Covid-19. Kebijakan pembelajaran daring, pemberian subsidi kuota, dan pengurangan tugas sekolah sebagai bentuk tindakan mengurangi risiko tertimpa Covid-19 dan meringankan beban psikologis, khususnya bagi peserta didik.

Kata Kunci: Kepala Madrasah, Manajer Risiko, Covid-19, Pembelajaran Daring

\section{PENDAHULUAN}

Kebijakan Work from Home (WFH) dan pembelajaran daring/jarak jauh pada masa pandemi Corona Virus Disease (Covid-19) yang belum pernah disiapkanterlebih dulu membuatkan beberapa lembaga pendidikan tidak siap karena minimnya pengalaman pembelajaran daring juga terkendala oleh minimnya sarana dan prasarana seperti jauhnya lokasi dengan jaringan sinyal internet yang kuat, kuota yang tidak memadai, serta rendahnya skill dalam menggunakan media-mediapembelajaran daring. Oleh karena itu, setiap guru dan peserta didikdiperlukan kemampuan untuk dapat mengantisipasi setiap perubahan dan ketidakpastian yang sedang terjadi maupun yang akan terjadi (Hermawan, 2017).

Kebijakan WFH dikeluarkan oleh MENPANRB, Tjahjo Kumolo sudah mengeluarkan Surat Edaran No. 57/2020 pada tanggal 28 Mei 2020 untuk mengatur perpanjangan kebijakan work from home (WFH) hingga Juni 2020 (https://menpan.go.id). Selain kebijakan WFH, Pemerintah Indonesia melalui Kemendikbud, Nadiem Anwar Makarim mengeluarkan Surat Edaran No. 4 Tahun 2020 tentang "Pelaksanaan Pendidikan Dalam Masa Darurat Covid-19" yang mengatur pembatalan ujian nasional (UN) tahun 2020, proses pembelajaran dari rumah melalui daring/jarak jauh, ujian sekolah, kenaikan kelas, dan Penerimaan Peserta Didik Baru (PPDB) dan penggunaaan dana Bantuan Operasional Sekolah (BOS) untuk pencegahan Covid-19.

Covid-19 adalah bentuk Pneumonia yang pertama kali ditemukan di Wuhan, ibu kota Provinsi Hubei China yang kemudian dilaporkan ke organisasi kesehatan dunia (WHO) pada 31 Desember 2019 (McAleer, 2020) (Wang et al., 2020). Pada 30 januari 2020,WHO mendeklarasikan "Kepedulian Internasional pada Darurat Kesehatan Masyarakat", setelah itu pada 11 februari 2020 WHO memberi nama virus tersebut Covid-19 (McAleer, 2020). Penamaan Covid-19 disebabkan oleh Severe Acute Respiratory Syndrome Coronavirus-2 (SARS-CoV-2). (Adityo Susilo, et al., 2020) Kasus dua orang positif Covid-19 pertama kali ditemukan di Indonesia pada 2 Maret 2020 (WHO Situation Report-42). Kasus ini kemudian menyebar luas ke beberapa daerah hingga Pemerintahan Indonesia mengeluarkan PP No 21 tahun 2020 tentang Pembatasan Sosial Berskala Besar (PSBB) hingga wacana 'New Normal atau kebiasaan baru'. 
Persoalan inilah yang mendorong seorang kepala sekolah (madrasah) harus kreatif mencari solusi dalam kondisi krisis pandemi Covid-19. Kepala madrasah dituntut mampu untuk mengelola risiko dengan baik, sebab kepemimpinannya merupakan faktor utama yang berpengaruh dalam pengembangan organisasi (Rohman \& Muna, 2018) serta dapat berinteraksi dengan para anggotanya dalam menghadapi perubahan dan tantangan untuk tercapainya tujuan bersama. (Rizal, 2019).

Kepala madrasah profesional akan memotivasi dan berperan penting dalam penentuan langkah-langkah efektif dalam kepemimpinan sekolah (Ja'far, 2019) serta dapat mendiskusikan proses perkembangan madrasah dan menumbuhkan rasa kebersamaan, keinginan, semangat dan potensi dari semua staf (SDM) (Santoso, 2018). Kepala sekolah (madrasah) memiliki posisi (kekuasaan) untuk mengatur, mengorganisir, serta mengontrol anggota organisasi untuk memprakarsai tingkah laku sosial. (L. Nurmiyati and Bach Yunof Candra, 2019) serta berperilaku sesuai dengan visi, misi, core values/belief organisasi (Husnan Abrori, 2018). Sehingga pemimpin dituntut memiliki kualitas dan seni memimpin dan memahami filosofi kehidupan (Rodliyah, 2019).

Karakter kepala madrasah (sekolah) inilah yang diharapkan dapat memberikan solusi dalam proses pembelajaran pada masa pandemi Covid-19. Seorang kepala madrasah minimal memiliki dua peran dalam mengelola madrasah, yaitu peran kepemimpinan dan manajerial. Kedua peran ini dapat seiring sejalan dalam manajemen madrasah dalam kondisi krisis. Atas dasar ini, kerangka teori untuk membahas persoalan ini adalah manajemen krisis. Bagaimana peran manajerial kepala madrasah dalam menghadapi krisis pandemi Covid-19 perspektif manajemen risiko.

\section{Teori Kepemimpinan Dan Manajemen Risiko}

Dalam perspektif Islam, proses kepemimpinan ini juga mengandung tujuan untuk mendapatkan ridha Allah (Noorrela Ariyunita, 2019). Definisi ini pun tak mengecualikan pemimpin-pemimpin pemangku kebijakan pendidikan dan pemimpin-pemimpin lembaga pendidikan di bawahnya(Ahmad Buchori Muslim, 2019). Dan setiap pemimpin akan dimintai pertanggungjawaban. Sebagaimana sabda Nabi Muhammad Saw, "Setiap kamu adalah pemimpin, dan setiap pemimpin akan diminta pertanggungjawaban pada orang yang dipimpinnya."(HR Bukhori-Muslim) (Hambali, 2017). Pemimpin juga berperan dalam menggerakan organisasi untuk mencapai tujuan, sehingga kepala sekolah (madrasah) harus mempunyai skill untuk memotivasi agar terjadi peningkatan kinerja(Miftachul Ulum\&Abdul Mun'im, 2019). Menjadi pemimpin adalah bagian dari sunnatullah (Mochamad Mukhlis, 2017). karena manusia diciptakan dimuka bumi sebagai Khalifah. 
Dalam al-Qur'an, kata Khalifah ditujukan kepada dua nabi, yaitu Nabi Adam as (QS. Al-Baqarah [2]: 30) dan Nabi Daud as (QS. Shad [38]: 26. Penunjukkan Nabi Adam as sebagai Khalifah bermakna bahwa setiap manusia (sebagai anak cucu Adam) mendapatkan amanah menjadi Khalifah yang akan dimintai pertanggungjawaban, sedangkan penunjukkan Nabi Daud as sebagai Khalifah dalam konteks hukum dan politik untuk menegakkan hukum Allah di tengah-tengah manusia.(A. Djalaluddin, 2014). Perbedaan keduanya bahwa Nabi Daud as diberikan amanah mengelola Palestina, sedangan Nab Adam as mengelola bumi sejak awal sejarah manusia(Shihab, 2014).

Sondang P Siagian (V. Amalia \& Z. Arifin, 2018)membagi lima tipe kepemimpinan yaitu otokratik, paternalistik, kharismatik, laissez fraire, dan demokratis. Setiap tipe kepemimpinan mengandung sikap (perilaku) atau gaya yang berbeda. Misalnya, Otokratik lebih dominan pada sikap otoriternya, Paternalistik pada sikap kebapakan, Karismatik pada karisma (karakter) pribadi yang luar biasa, Laissez. Fraire pada sikap permisif, dan demokratis lebih dominan pada pelibatan peran serta anggota organisasi dalam pengambilan keputusan.

Gaya kepemimpinan (leadership style) menggambarkan perilaku pemimpin untuk menghadapi atau berinteraksi dengan situasi (Zuwesty Eka Putri, 2014) yang juga merupakan cara untuk mempengaruhi orangagar berbuat dalam pencapaian tujuan organisasi walaupun secara pribadi mereka tidak menyukainya (Saputro i Nugroho Widh \& Erma Setyawati, 2015).

Kepemimpinan memiliki peran yang sangat strategis dalam menciptakan good governance sehingga diperlukan pendidikan dan pelatihan bagi pemimpin untuk memperkuat manajemen instansi. (Rostiawati, 2020) Menurut Syahrul (dalam Bashori) pemimpin berperan dalam menghadapi perubahan organisasi, respon terhadap krisis, pertumbuhan untuk mencapai tujuan organisasi, keyakinan yang kuat tentang cita-cita bersama, dan sinergi semua komponen (Bashori, 2019). Pemimpin yang baik memiliki kepedulian dan kepekaan terhadap kebutuhan orang-orang yang dipimpinnya sehingga mereka bersedia untuk mendiskusikan impian dan harapan (Purwanto et al., 2020).

\section{Manajemen Risiko}

Manajemen Risiko merupakan metode logis dan sistematis untuk mengidentifikasi, kuantifikasi, penentuan sikap, penetapan solusi, monitoring, dan pelaporan risiko pada setiap aktivitas. Risiko diartikan sebagai ancaman atau tindakan yang menimbulkan dampak berlawanan dengan tujuan. (Risa Safariyani, 2011). Risiko dapat disebabkan oleh ketidakpastian ekonomi, alam maupun manusia. (Soeisno Djojosoedarso, 2003) dan ketidakpastian ini dapat diukur secara kuantitatif (Bramantyo Djohanoputro, 2006). 
Setiap aktivitas memiliki berbagai risiko yang berdampak pada kerugian, akan tetapi risiko juga dapat dikelola dengan baik untuk menciptakan peluang memperoleh keuntungan besar (Risa Safariyani, 2011). Begitu juga dengan risiko adanya pandemi Covid-19 perlu dikelola dengan baik agar tidak menimbulkan dampak buruk dalam penyelenggaran pendidikan. Pandemi ini juga dapat memberikan peluang kreativitas bagi kepala sekolah/madrasah untuk tetap menyelenggarakan pendidikan secara daring melalui berbagai media e-learning.

Kerangka kerja manajemen risiko meliputi tiga hal, yaitu: penilaian risiko (risk assessment), peringanan risiko (risk mitigation) dan evaluasi risiko (risk evaluation). Menurut Gibson (dalam Nurochman), manajemen risiko merupakan kegiatan untuk mengidentifikasi, menilai, mengontrol, dan meringankan risiko. Gambaran kegiatan manajemen risiko pada proses pembelajaran daring di masa pandemi Covid-19 sebagai metode terstruktur yang menggambarkan tahaptahap manajemen risiko, yaitu penilaian risiko, peringanan risiko dan evaluasi risiko. (Arif Nurochman, 2014).

Manajemen risiko pada tahap perkembangan menggunakan pendekatan parsial atau Traditional Risk. Management (TRM) yang masih kuat tradisi egosektoral yang tidak mau saling berbagi informasi untuk kemajuan. Pendekatan manajemen risiko terbaru adalahholistik atau disebut dengan Enterprise Risk Management (ERM) atau Integrated Risk Management (IRM) dan Strategic Risk Management (SRM) yang dapat melakukan mitigasi risiko sejak dini dan komprehensif (Oka Aditya, 2017).

Efektivitas manajemen risiko pada suatu organisasi jika menganut prinsip-prinsip berikut ini, (1) memiliki nilai tambah, (2) terpadu dari proses organisasi, (3) bagian dari proses pengambilan keputusan, (4) khusus menangani aspek ketidakpastian, (5) bersifat sistemik, terstruktur, tepat waktu, (6) berdasarkan informasi terbaik yang tersedia, (7) khas untuk penggunanya, (8) mempertimbangkan faktor manusia dan budaya, (9) transparan dan inklusif, (10) bersifat dinamis, berulang, tanggap terhadap perubahan, dan (11) memfasilitasi terjadinya perbaikan dan peningkatan organisasi secara berkelanjutan.(Risa Safariyani, 2011) Menurut Soeisno Djojosoedarso (Safariyani), manajemen risiko bertujuan untuk menanggulangi kerugian, mengurangi kecemasan dan ketakutan, serta menyelamatkan perusahaan (instansi) (Risa Safariyani, 2011).

Dalam menghadapi potensi risiko yang telah, sedang, dan akan terjadi maka diperlukan peran manajemen risiko yang baik dan tepat. Risiko pada umumnya terkait dengan ketidakpastian, sebagai kejadian yang mungkin atau tidak mungkin terjadi, risiko menggambarkan ketidakpastian atau ancaman (Kannan dan Thangavel dalam Hermawan, 2017). Atas dasar ini, kepala madrasah harus siap menghadapi risiko yang kadang datang secara tiba-tiba 
194 | Tadbir : Jurnal Studi Manajemen Pendidikan, Vol. 4, No. 2, 2020

seperti pandemi Covid-19 yang memaksa perubahan proses kegiatan belajarmengajar dan pengawasan pegawai secara daring.

\section{METODE PENELITIAN}

Penelitian ini penting dilakukan untuk mengungkapkan bagaimana peran kepala madrasah dalam proses pembelajaran daring di masa pandemi Covid-19 perspektif manajemen risiko. Penelitian ini dilakukan di MTs N 1 Yogyakarta dengan pendekatan kualitatif. Data dikumpulkan melalui observasi dan wawancara mendalam (in-depth interview) secara purposive (Sugiyono, 2010). Kepada kepala madrasah, guru, dan orangtua peserta didik. Validasi data dilakukan dengan mentriangulasi antar narasumber. Data dianalisis secara interaktif meliputi tiga kegiatan, yaitu reduksi data, penyajian data, dan penarikan kesimpulan (verifikasi)(Matthew B. Miles \& A. Michael Huberman, 1984).

\section{HASIL PENELITIAN DAN PEMBAHASAN}

\section{Peran Kepala Madrasah Sebagai Manajer Risiko}

Kepala madrasah sebagai seorang manajer memiliki tanggungjawab dalam mengelola madrasah dalam kondisi apapun. Seorang kepala madrasah harus memiliki inisiatif dalam setiap kondisi dan menjaga proses manajerial tetap berjalan, walaupun dalam kondisi krisis. Di sinilah diperlukan peran kepala madrasah sebagai manajer risiko dalam meminimalisir (mengurangi) dampak buruk pandemi Covid-19 yang akan menimpa seluruh stakeholders, khususnya guru dan peserta didik.

Kerangka kerja manajemenrisiko dalam proses pembelajaran di masa pandemi Covid-19 di MTS N 1 Yogyakarta meliputi tiga tahapyaitu: penilaian risiko, peringanan (mitigasi) risiko dan evaluasi risiko. Pertama, penilaian risiko. Seorang kepala madrasah sebagai seorang manajer risiko harus memahami risiko dengan baik sehingga sebelum mengambil keputusan atau kebijakan maka harus terlebih dahulu menilai risiko apa yang akan terjadi, baik risiko sebelum terjadi maupun risiko apa yang akan ditimbulkan setelah proses tersebut.

Menurut Bapak Iriyadi (Kepala MTs N 1) bahwaproses penilaian risiko yang dilakukan di MTsN 1 Yogyakarta dalam mengelola pembelajaran di masa pandemi Covid-19 dengan langkah-langkah berikut, yaitu: (1) melakukan rapat dengan seluruh steakholders madrasah untuk mengetahui masalah yang akan dihadapi dalam masa pandemi Covid-19, (2) mengidentifikasi risiko yang akan terjadi bersama para guru dan wakil kepala madrasah bidang kurikulum, dan (3) melakukan musyawarah untuk mencari solusi atas persoalan pembelajaran di masa pandemi Covid-19, yaitu kebijakan pembelajaran secara daring. 
Musyawarah dengan stakeholders untuk mencari solusi dalam kondisi krisis merupakan bentuk kepemimpinan partisipatif. Hubungan partisipatif ini dapat melahirkan motivasi dan spirit dalam pengembangan lembaga secara bersama-sama. (Ahmad Sabri \& Heri Priyanto, 2020) Partisipasi aktif kepala madrasah akan mendorong baru semua stakeholders untuk turut memberikan pendapatnya dalam penanganan krisis pembelajaran di masa pandemi Covid-19.

Menurut Bapak Agung (Guru MTsN 1), penilaian risiko atas kebijakan belajar secara daring dari rumah pada masa pandemi Covid-19 adalah kebijakan yang sangat tepat. Guru masih dapat memberikan materi kepada peserta didik melalui pelbagai media, whatsapp, google classroom, e-learning, dan lain sebagainya. Kebijakan tersebut kondisional tidak memberatkan bagi guru karena disesuaikan dengan keadaan dan kemampuan masing masing guru.

Kedua, peringanan risiko atau proses mitigasi. Proses peringanan risiko yang dilakukan di MTsN 1 Yogyakarta dengan membuat kebijakan pembelajaran daring di rumah untuk mencegah penyebaran Covid-19 di madrasah. Agar pembelajaran daring tidak memberatkan bagi guru dan peserta didik, kepala MTs N 1 (Bapak Iriyadi) mengambil kebijakan, yaitu: (1) memberikan subsidi kuota internet kepada para guru untuk melakukan proses pembelajaran dari daring dari rumah, (2) pembatasan pembelajaran daring, yaitu sehari tidak boleh lebih dari dua mata pelajaran agar tidak membebani peserta didik ketika belajar dari rumah, dan (3) menginstruksikan kepada para guru agar tidak memberikan banyak tugas kepada peserta didik pada masa pandemi Covid-19.

Menurut Ibu Eka (Wali Peserta didik), bahwa peringanan (mitigasi) risiko melalui kebijakan pembelajaran daring dari rumah sangat membantu mengurangi terpaparnya Covid-19, walaupun tidak semua peserta didik mempunyai fasilitas yang sama terkait kuota atau sinyal internet. Pembelajaran daring sangat membantu para peserta didik belajar dengan baik di masa pandemi Covid-19 walaupun tidak begitu efektif.

Menurut Dafa Akbar (siswa kelas IX) proses belajar mengajar menggunakan Daring (Online) cukup nyaman, karena dia sudah familiar dengan berbagai aplikasi belajar yang disampaikan oleh para guru. Para guru menggunakan berbagai aplikasi seperti Quir, google classroom, e-mail, whatsapp, dan lain-lain. Selain itu baginya tidak ada kendala terkait kuota, karena dia termasuk siswa yang mampu. Bagi siswa yang mempunyai keterbatasan ekonomi untuk membeli kuota, maka pihak sekolah menyuruh ketua kelas untuk mendata, yang kemudian akan dihubungi oleh pihak sekolah dan akan diberi bantuan kuota. Sehingga semua siswa dengan ini dapat mengikuti pembelajaran semuanya dengan baik. 
Ketiga, adalah evaluasi risiko. Menurut Bapak Iriyadi (kepala MTs N 1) bahwa proses evaluasi risiko yang dilakukan MTs N 1 Yogyakarta, yaitu: (1) menampung semua laporan dan keluhan baik dari para guru maupun dari wali peserta didik yang merasa terbebani atau keberatan dengan proses pembelajaran daring dari rumah, (2) melakukan rapat kembali dengan para guru dan seluruh steakholders untuk mengevaluasi apa yang terjadi dilapangan, dan (3) penjadwalan piket secara bergantian kepada pada guru (minimal 30\% dari jumlah guru) untuk Work from Office (WFO) atau kerja dari kantor untuk memberikan pelayanan pendidikan.

Evaluasi risiko penting dilakukan untuk mengetahui seberapa besar dampak krisis yang belum tertangani sehingga dapat diminimalisir kerugian atau keburukan yang menimpa organisasi. Menurut Ali Murfi, dkk bahwa kepala sekolah/madrasah perlu membangun pendekatan kolaboratif dalam mengevaluasi dampak krisis untuk mencegah krisis di masa mendatang. (Ali Murfi, et.al., 2020)

\section{KESIMPULAN}

Berdasarkan penelitian tentang peran kepala MTs N 1 Yogyakarta dalam proses pembelajaran daring pada masa pandemi Covid-19 perspektif manajemen risiko dapat disimpulkan bahwa kepala madrasah sebagai manajer risiko telah melakukan tiga tahap manajemen risiko, yaitu (1) penilaian risiko untuk mengetahui dan mengindetifikasi masalah pembelajaran daring pada masa pandemi Covid-19, (2) peringanan risiko, untuk meringankan beban bagi guru dan peserta didik dalam proses pembelajaran melalui kebijakan pemberian subsidi kuota internet bagi guru dan peserta didik yang tidak mampu dan tidak memberikan tugas terlalu banyak kepada peserta didik, dan (3) evaluasi risiko, untuk melihat problem proses pembelajaran daring melalui laporan atau keluhan baik dari guru maupun peserta didik.

Peran kepala madrasah sebagai Manajer Risiko harus bisa meminimalisir, bahkan menghilangkan risiko atau dampak buruk proses pembelajaran pada masa pandemi Covid-19. Kebijakan pembelajaran daring, pemberian kuota internet bagi guru dan peserta didik yang tidak mampu, dan pengurangan tugas atau Pekerjaan Rumah (PR) bagi peserta didik sebagai bentuk tindakan mengurangi risiko tertimpa Covid-19 dan meringankan beban psikologis, khususnya bagi peserta didik. Untuk menghindari kebosanan dalam pembelajaran daring, guru dituntut mengembangkan strategi aktif, kreatif, inovatif, dan menyenangkan melalui sarana teknologi, misalnya pembuatan video, video call, youtube, instagram, dan lain sebagainya. Sebagai seorang kepala sekolah atau manager sekolah sudah sepatutnya harus merencanakan dan mengantisipasi resiko yang akan terjadi setelahnya, termasuk ketika peralihan 
system pembelajaran dari luring ke daring, sehingga akibat yang negative dapat di minimalisir dengan baik.

\section{REFERENSI}

Abrori, H. (2018). Inspiring Leadership dan Transformasi Kelembagaan. AlTanżim : Jurnal Manajemen Pendidikan Islam, 2(1), 1-22.

Ariyunita, N. (2019). Pengaruh Gaya Kepemimpinan Kepala Madrasah Terhadap Kinerja Pendididik dan Kependidikan di Madrasah Ibtidaiyah (MI) Al Huda Maguwo, Sleman. Evaluasi, 3(1), 30-46.

Amalia, V., \& Arifin, Z. (2018). Kepemimpinan Nyai dalam Memelihara Kajian Kitab Kuning di Ma'had Aly Nurul Jadid Probolinggo. MANAGERIA: Jurnal Manajemen Pendidikan Islam, 3(2), 215-230.

Aditya, Oka, Prima. N. (2017). Penerapan Manajemen Risiko Perusahaan dan Nilai Perusahaan di Sektor Konstruksi dan Properti. ESENSI: Jurnal Bisnis Dan Manajemen, 7(2), 167-180. https://doi.org/10.15408/e ss.v7i2.4981

Bashori. (2019). Kepemimpinan Tansformasional Kyai pada Lembaga Pendidikan Islam. Al-Tanæim: Jurnal Manajemen Pendidikan Islam, 03(02), 73-84.

Djalaluddin. A. (2014). Manajemen Qur'ani: Menerjemahkan idarah ilahiyah dalam kehidupan insaniyah. In UIN-Maliki Press (2nd ed.). UIN-Maliki Press.

Djohanoputro. Bramantyo. (2006). Manajemen Risiko Korpotat Terintegrasi. Jakarta: Penerbit PPM.

Djojosoedarso. Soeisno. (2003). Prinsip-Prinsip Manajemen Risiko Asuransi. Jakarta: Salemba Empat.

Hambali, M. (2017). Kepemimpinan Berbasis Core Values Sekolah Unggulan di Malang. MANAGERIA: Jurnal Manajemen Pendidikan Islam, 2(1), $19-43$.

Hermawan, V. (2017). Asesmen Maturitas Manajemen Risiko Untuk Organisasi Publik Pengguna Jasa Dan Korelasinya Terhadap Kinerja, Tesis, Universitas Katolik Parahyangan.

Https://menpan.go.id

Ja'far. (2019). Inovasi Kepemimpinan Kepala Madrasah Kreatif Dalam Meningkatkan Mutu Pendidikan di Sekolah Evaluasi, 3(1), 74-103.

McAleer, M. (2020). Prevention Is Better Than the Cure: Risk Management of 
198 | Tadbir : Jurnal Studi Manajemen Pendidikan, Vol. 4, No. 2, 2020

Covid-19. Journal of Risk and Financial Management, 13(3), 46. https://doi.org/10.3390/jrfm13030046

Muslim. Ahmad Buchori. (2019). Konsep Kepemimpinan Perspektif Tasawuf Positif Modern Ahmad. Evaluasi, 3(1), 136-161.

Mukhlis. Mochamad. (2017). Model dan Bentuk Kepemimpinan Dalam Islam. Al-Tanzim: Jurnal Manajemen Pendidikan Islam, 1(1), 88-98.

Murfi, Ali. Irwan F. Atika. Nora S.J. (2020). Kepemimpinan Sekolah Dalam Situasi Krisis Covid-19 di Indonesia. MANAGERIA: Jurnal Manajemen Pendidikan Islam, 5 (1), 119-136.

Miles. M.B. \&Huberman A. M. (1984). Qualitative Data Analysis A Sourcesbook of New Methods. London New Delhi: Sage Publications.

Nurmiyati,L. \& Candra, B. Y. (2019). Kepemimpinan transformasional dalam peningkatan mutu pendidikan anak usia dini. Al-Tanzim: Jurnal Manajemen Pendidikan Islam, 03(02), 13-24.

Nurochman. Arif. (2014). Manajemen Risiko Sistem Informasi Perpustakaan (Studi Kasus di Perpustakaan Universitas Gadjah Mada Yogyakarta).Berkala Ilmu Perpustakaan dan Informasi, 10(2), 1-13.

Purwanto, A., Asbari, M., Prameswari, M., Ramdan, M., Harapan, P., Harapan, U. P., Harapan, U. P., Dan, A., \& Guru, K. (2020). Gaya Kepemimpinan di Madrasah Aliyah: Authentic, Tansformational, Authoritarian atau Transactional? Nidhomul Haq: Jurnal Manajemen Pendidikan Islam, 5(1), 1531.

Putri. Zuwesty Eka. (2014). Pengaruh Partisipasi Anggaran, Komitmen Organisasi, Gaya Kepemimpinan Terhadap Kinerja Manajerial. Esensi: Jurnal Bisnis Dan Manajemen, 4(3), 137-160.

Rizal, S. (2019). Servant Leadership Dalam Implementasi Nilai-Nilai Trilogi Dan Panca Kesadaran Santri. Evaluasi, 3(2), 162-182.

Rodliyah, S. (2019). Leadership Pesantren: Urgensi Pendidikan dalam Menyiapkan Pemimpin Bangsa Berkualitas dan Bermoral. MANAGERIA: Jurnal Manajemen Pendidikan Islam, 4(1), 169-182.

Rohman, F. A., \& Muna, N. (2018). Kepemimpinan Demokratis Kepala Madrasah Ibtidaiyah ( MI ) Nurul Ummah Kotagede Yogyakarta. MANAGERIA: Jurnal Manajemen Pendidikan Islam, 3(2), 269-288.

Rostiawati, E. (2020). Efektifitas Manajemen Kepemimpinan Dalam Menciptakan Good Governance. Al-Tanżim: Jurnal Manajemen Pendidikan 
Islam, 04(01), 59-69.

Safariyani. Risa. (2011). Manajemen Risiko Pembiayaan Al-Istishnâ Pada BPRS Amanah Ummah, Leuwiliang-Bogor, Skripsi, UIN Syarif Hidayatullah Jakarta.

Santoso, W. H. (2018). Kepemimpinan Transformasional Kepala Madrasah Dalam Membangun Karakter Siswa di Mi Ma'arif Bego Depok Sleman. Nidhomul Haq : Jurnal Manajemen Pendidikan Islam, 3(2), 57-75.

Sabri,Ahmad \& Heri Priyanto. (2020). Kepemimpinan Ketua Yayasan Shine AlFalah Pada Pondok Pesantren Perkampungan Minangkabau Dalam Pendidikan Kaum Dhuafa Kota Padang. TADBIR: Jurnal Studi Manajemen Pendidikan, 4 (1), 1-16.

Shihab, M. Q. (2014). Membumikan Al-Quran Fungsi dan Peran Wabyu dalam Kehidupan Masyarakat. Bandung: PT Mizan Pustaka.

Sugiyono. (2010). Metode Penelitian Pendidikan Pendekatan Kuantitatif, Kualitatif, dan R\&D. Bandung: Alfabeta.

Susilo, Adityo. C. Martin Rumende, Ceva W Pitoyo, Widayat Djoko Santoso, Mira Yulianti, Herikurniawan, Robert Sinto, Gurmeet Singh, Leonard Nainggolan, Erni J Nelwan, Lie Khie Chen, Alvina Widhani, Edwin Wijaya, Bramantya Wicaksana, Maradewi Maksum, Firda Annisa, Chyntia OM Jasirwan, Evy Yunihastuti(2020). Coronavirus Disease 2019: Tinjauan Literatur Terkini Coronavirus Disease 2019: Review of Current Literatures. Jurnal Penyakit Dalam Indonesia, 7 (1): 45-67.

Ulum, Miftachul\&Abdul Mun'im, M. (2019). Pengaruh Kepemimpinan Terhadap Prestasi Kerja Karyawan di Madrasah Mu'allimin Mu'allimat Pondok Pesantren Sunan Drajat Lamongan.Evaluasi, 3(2), 209-231.

Widh. Saputro Nugrohoi\&Erma Setyawati. (2015). Pengaruh Independensi, Gaya Kepemimpinan, Komitmen Organisasi dan Pemahaman Good Governance Terhadap Kinerja Auditor Pemerintah. Benefit: Jurnal Manajemen dan Bisnis, 19(1), 64-79.

Wang, C., Cheng, Z., Yue, X.-G., \& McAleer, M. (2020). Risk Management of COVID-19 by Universities in China. Journal of Risk and Financial Management, 13(2), 36. https://doi.org/10.3390/jrfm13020036 
200 | Tadbir : Jurnal Studi Manajemen Pendidikan, Vol. 4, No. 2, 2020

This page belongs to the TADBIR : Jurnal Studi Manajemen Pendidikan

TADBIR : Jurnal Studi Manajemen Pendidikan vol. 4, no. 2, November 2020

IAIN Curup - Bengkulu | p-ISSN 2580-3581; e-ISSN 2580-5037 